\title{
Soil behaviour of metamitron in laboratory and lysimeter studies
}

\author{
C Vischetti ${ }^{*}$, C Marucchini², L Leita ${ }^{3}$, P Ceccon $^{4}$, R Giovanardi $^{4}$ \\ 'Centro di Studio sulla Chimica e Biochimica dei Fitofarmaci CNR, Borgo XX Giugno 72, 06121 Perugia, Italy \\ 2Istituto di Chimica Agraria dell'Università, Borgo XX Giugno 72, 06121 Perugia, Italy \\ ${ }^{3}$ Istituto Sperimentale Nutrizione Piante SOP, via Trieste 23, 34170 Gorizia, Italy \\ ${ }_{4}^{4}$ Dipartimento di Produzione Vegetale e Tecnologie Agrarie dell'Università, Via delle Scienze 208, 33100 Udine, Italy
}

(Received 4 April 1997; accepted 11 December 1997)

\begin{abstract}
Summary - The fate of metamitron, a sugar beet herbicide, in soil was studied in laboratory and in field lysimeters under different water regimes. Laboratory degradation followed first-order kinetics with half-lives ranging from 18.8 to $56.3 \mathrm{~d}$ with different incubation conditions. Lysimeter dissipation was consistently rapid with half-lives ranging from 4.4 to $8.0 \mathrm{~d}$ under the different water regimes. The influence of temperature on laboratory degradation was within the range reported for many other pesticides, while that of soil moisture was lower than for other pesticides. Adsorption was well described by an L-type isotherm with a $1 / n$ value far from unity in common with most polar herbicides. Metamitron movement through the lysimeters varied with the different amounts of water supplied. Metamitron reached $60 \mathrm{~cm}$ in depth at day 7 after treatment and $120 \mathrm{~cm}$ in depth at day 14 after treatment in lysimeters that received normal water amounts and about $10 \%$ of pesticide moved below $120 \mathrm{~cm}$ in lysimeters that received, in addition to the normal water, $151 \mathrm{~mm}$ water at day 4 after treatment, which simulates a probable spring rain event in northern Italy. The marked movement of the pesticide in these conditions suggests that it is to be considered a potential pollutant in irrigated crops but, the rapid disappearance (DT50 4-8 days) of the pesticide in the lysimeters by means other than leaching, partially reduces this risk. (๑ Inra/Elsevier)
\end{abstract}

\section{metamitron / pesticide sorption / pesticide degradation / field lysimeters}

Résumé - Étude du comportement de la métamitrone dans le sol au laboratoire et dans des cases lysimétriques. Le devenir dans le sol d'un herbicide destiné aux betteraves à sucre, la métamitrone, a été étudié au laboratoire et au champ dans des cases lysimétriques sous différents régimes hydriques. La dégradation au laboratoire a suivi une cinétique du premier ordre avec des demi-vies comprises entre 18,8 et 56,3 j pour différentes conditions d'incubation. La dégradation dans les cases lysimétriques a été sensiblement plus rapide avec des demi-vies comprises entre 4,4 et 8,0 j sous différents régimes hydriques. L'influence de la température sur la dégradation au laboratoire a été du même ordre de grandeur que celle qui est reportée pour beaucoup d'autres pesticides alors que celle de l'humidité du sol a été plus faible que pour les autres pesticides. $L$ 'adsorption est bien décrite par des isothermes en $L$ avec une valeur de $1 / n$ loin de l'unité comme pour la plupart des herbicides polaires. Les mouvements de la metamitrone à l'intérieur des lysimètres ont varié en fonction des différentes quantités d'eau apportées. La metamitrone a ainsi atteint la profondeur de $60 \mathrm{~cm} 7 \mathrm{j}$ après son application, $120 \mathrm{~cm} 14 \mathrm{j}$ après son application dans les lysimètres qui ont reçu les quantités normales d'eau. Dans les lysimètres qui ont reçu en plus de la quantité normale d'eau, $151 \mathrm{~mm} 4 \mathrm{j}$ après l'application, ce

Article communicated by Marco Trevisan (Piacenza)

* Correspondence and reprints

Tel: +39 75 5856242; fax +39 75 5856239; e-mail: vischett@unipg.it 
qui simulait un événement pluvieux probable au printemps en Italie du nord, environ $10 \%$ du pesticide se sont déplacés au-dessous de $120 \mathrm{~cm}$. Le déplacement marqué du pesticide dans ces conditions suggère qu'il peut être considéré comme un polluant potentiel dans les cultures irriguées, mais sa disparition rapide (demi-vie : 4 à 8 j) dans les lysimètres par des mécanismes autres que le lessivage, réduit partiellement ce risque. (@ Inra/Elsevier)

\section{metamitrone / adsorption de pesticides / dégradation de pesticides / lysimètres au champ}

\section{INTRODUCTION}

Metamitron, 4-amino-3-methyl-6-phenyl-1,2,4triazin-5(4H)-one, is a herbicide that has been used in Italy for 30 years on sugar beet for the post-emergence control of annual broad-leaved weeds and grasses.

Numerous studies have been carried out on the degradation in soil of metamitron (Allen and Walker, 1987; Capri et al, 1995; Vischetti et al, 1996), with laboratory half-lives ranging from 7 to $50 \mathrm{~d}$ depending on soil and incubation conditions. Studies on sorption (Allen and Walker, 1987; Franco et al, 1997) show that there is relatively little retention of metamitron by soil constituents and a preference for the herbicide to move downward with soil solution. Some studies on the fate of metamitron under field conditions in the Mediterranean area (Capri et al, 1995; Trevisan et al, 1995) have suggested a low hazard of groundwater pollution. This may have been because the herbicide remained in the top-soil layer owing to the lack of rainfall during the experiments.

In this paper the degradation of metamitron in a sandy clay loam soil was studied in the laboratory at various temperatures and soil moisture contents and the adsorption isotherm for metamitron was determined. In addition, the movement of metamitron was studied in six field lysimeters under a rain shelter, which were cultivated with sugar beet and irrigated with different water volumes to evaluate the influence of water flow on pesticide movement.

\section{MATERIALS AND METHODS}

\section{Soil and herbicide}

A sandy clay loam soil was used for both sorption and degradation studies under laboratory conditions and the lysimeter trial (table I). Analyses were carried out according to Page (1982) and Klute (1986) for physicochemical properties. Analytical-grade metamitron (99.0 \% purity), produced by the Institute of Organic Industrial Chemistry, Warsaw, Poland, was used as the analytical standard. For the lysimeter trial a commer-
Table I. Main properties of the soil used.

\begin{tabular}{|c|c|}
\hline Sand $(\%)$ & 49 \\
\hline Silt $(\%)$ & 23 \\
\hline Clay $(\%)$ & 28 \\
\hline Field capacity (w/w, $0.033 \mathrm{MPa})$ & 24.5 \\
\hline Wilting point $(\mathrm{w} / \mathrm{w}, 0.15 \mathrm{MPa})$ & 10.5 \\
\hline $\mathrm{pH}\left(\mathrm{H}_{2} \mathrm{O}\right)$ & 7.5 \\
\hline Organic matter $(\%)$ & 2.8 \\
\hline CEC $(\mathrm{meq} / 100 \mathrm{~g})$ & 16.5 \\
\hline Bulk density $0-30 \mathrm{~cm}\left(\mathrm{~g} \mathrm{~cm}^{-3}\right)$ & 1.10 \\
\hline Bulk density $30-60 \mathrm{~cm}\left(\mathrm{~g} \mathrm{~cm}^{-3}\right)$ & 1.30 \\
\hline Bulk density $60-90 \mathrm{~cm}^{\left(\mathrm{g} \mathrm{cm}^{-3}\right)}$ & 1.38 \\
\hline Bulk density $90-120 \mathrm{~cm}^{\left(\mathrm{g} \mathrm{cm}^{-3}\right)}$ & 1.42 \\
\hline
\end{tabular}

cial product (Goltix) containing $70 \%$ active ingredient (ai) was used.

\section{Degradation studies}

A $100 \mathrm{~g}$ portion of finely powdered soil sample was placed in a $250 \mathrm{~mL}$ flask and a $150 \mathrm{~mL}$ acetone solution containing $9 \mathrm{mg}$ of metamitron was added. After the complete evaporation of acetone, appropriate amounts of the powdered soil were used to fortify three $1 \mathrm{~kg}$ samples of $2 \mathrm{~mm}$ sieved fresh-air dried soil in order to obtain a final concentration in the three soil samples of $3.0 \mathrm{mg} \mathrm{kg}-1$. Each of the containers was covered with a bored tin-foil and incubated in the dark at different temperatures and soil moisture conditions $120{ }^{\circ} \mathrm{C}$ and $75 \%$ field capacity (fc); $20^{\circ} \mathrm{C}$ and $33 \%$ fc; $10{ }^{\circ} \mathrm{C}$ and $75 \% \mathrm{fc}$. Soil moisture contents were maintained by daily additions of water. At different times after treatment, duplicate $50 \mathrm{~g}$ samples from each container were extracted and analyzed.

\section{Adsorption studies}

Duplicate amounts of air-dried soil (20 g), passed through a $2 \mathrm{~mm}$ sieve, were mechanically shaken for 16 $\mathrm{h}$ at $20^{\circ} \mathrm{C}$ with aqueous solutions $(100 \mathrm{~mL})$ of the herbicide in $0.01 \mathrm{M} \mathrm{CaCl}_{2}$. Initial concentrations were $0.50,1.00,1.50,2.00$ and $2.50 \mathrm{mg} \mathrm{L}^{-1} ; \mathrm{pH}$ of the suspensions was 7.0. After shaking, the suspensions were centrifuged for $20 \mathrm{~min}$ at $6089 \mathrm{~g}$. The supernatants were filtered and extracted with chloroform $(3 \times$ $50 \mathrm{~mL}$ ), separated in a separating funnel, evaporated in a rotary evaporator at $40^{\circ} \mathrm{C}$, redissolved in methanol $(1 \mathrm{~mL})$ and then analyzed. 


\section{Field lysimeter experiment}

The trial was carried out at the Experimental Farm of the University of Udine, northern Italy $\left(46^{\circ} 2^{\prime} \mathrm{N}\right.$, $13^{\circ} 13^{\prime} \mathrm{E}, 110 \mathrm{~m}$ asl), in six lysimeters, $1.5 \times 1.5 \times 1.5$ $m$ in size, buried on level in a field plot $\left(200 \mathrm{~m}^{2}\right)$ and covered by a shelter. The lysimeters were filled with the soil described in table I. In 1987, a bulk of farm topsoil was sieved and tamped layer after layer by successive saturations on a gravel draining layer in each iron tank. The experimental layout of the trial entailed three water regimes with two replications and three different types of lysimeter: i) weighing lysimeters (numbers 1 and 2 in table II), where crops were kept well watered by restoring the entire crop evapotranspiration whenever $30 \mathrm{~mm}$ of soil water had been depleted; irrigations were carried out by a drip irrigation system with emitters $0.5 \mathrm{~m}$ apart delivering $6 \mathrm{~mm} \mathrm{~h}^{-1}$; ii) lysimeters with a permanent water table placed at $0.5 \mathrm{~m}$ from the soil surface (numbers 3 and 4 in table II), where water was supplied to the water table from the bottom of the lysimeters according to guage readings; iii) drainage lysimeters (numbers 5 and 6 in table II), where crops were grown as in i) but where copious amounts of water were applied at days 4 and 56 after herbicide application ( $15 \mathrm{l}$ and $93 \mathrm{~mm}$, respectively, in $24 \mathrm{~h}$ ). Leachates were collected at the bottom of the lysimeters and measured. Three $200 \mathrm{~mL}$ samples were stored at $-10{ }^{\circ} \mathrm{C}$ before analytical determinations.

The experiments described in ii) and iii) were performed to simulate the climate typical of northeast Italy, where heavy rainfall occurring during springtime may induce both the establishment of a shallow water table and heavy leaching though the soil profile.

Sugarbeet (Beta vulgaris L var saccharifera) was sown on 14 March 1995 in and around the lysimeters. According to the traditional farming management in the area, pre-emergence herbicide treatment was applied using a commercially formulated product (Goltix, $70 \%$ ai) at the recommended rate of $5 \mathrm{~kg} \mathrm{ha}^{-1}$ in $800 \mathrm{~L} \mathrm{ha}^{-1}$ of water, thus distributing $3.5 \mathrm{~kg} \mathrm{ha}^{-1}$ ai. Soil cores were taken at various increments to a depth of $120 \mathrm{~cm}$ at different times after treatment and duplicate $50 \mathrm{~g}$ samples for each increment were extracted and analyzed. The holes were refilled with the same soil type immediately after collection so as to avoid any changes in leaching patterns.

\section{Analyses}

Soil residues of metamitron were extracted with methanol $(2 \times 100 \mathrm{~mL} \times 2 \mathrm{~h})$ and the extracts were diluted in water $(150 \mathrm{~mL})$, partitioned in chloroform ( 3 $\times 100$ ), evaporated to dryness and rinsed with methanol (1 mL).

Water samples were directly partitioned in chloroform $(2 \times 100 \mathrm{~mL})$, evaporated to dryness and rinsed with methanol ( $1 \mathrm{~mL})$.

These samples, together with those from the adsorption studies, were analyzed by HPLC according to the
Table II. Irrigations applied in the six lysimeters $(\mathrm{mm})$.

\begin{tabular}{|c|c|c|c|}
\hline \multirow[t]{2}{*}{$\begin{array}{l}\text { Days after } \\
\text { application }\end{array}$} & \multicolumn{3}{|c|}{ Lysimeter No } \\
\hline & $1-2$ & $3-4$ & $5-6$ \\
\hline 0 & 3.1 & 3.1 & 3.1 \\
\hline 2 & 5.8 & 5.8 & 5.8 \\
\hline 4 & & & 151 \\
\hline 8 & 5.3 & 3.6 & 2.2 \\
\hline 11 & 5.3 & 5.3 & 2.7 \\
\hline 21 & 3.1 & 3.1 & 3.1 \\
\hline 42 & 4.4 & & \\
\hline 45 & 6.7 & 6.7 & 6.7 \\
\hline 50 & 30 & & 30 \\
\hline 56 & & & 93 \\
\hline 64 & 30 & & \\
\hline 67 & & & 15.6 \\
\hline 70 & 30 & & 17.8 \\
\hline 77 & 30 & & 30 \\
\hline 81 & 30 & & 30 \\
\hline 88 & 30 & & 30 \\
\hline 92 & 30 & & 30 \\
\hline 95 & 40 & & 40 \\
\hline 101 & 40 & & 40 \\
\hline 105 & 40 & & 40 \\
\hline
\end{tabular}

procedure described by Ghebbioni and Trevisan (1992).

Average recoveries were $91.4 \%(\mathrm{sd} \pm 5.2)$ from soil and $98.7 \%( \pm 0.4)$ from water and quantification limits were 9.8 and $6.3 \mu \mathrm{g} \mathrm{kg}^{-1}$ from soil and water samples, respectively.

\section{Calculations}

Laboratory half-lives $\left(\mathrm{t}_{1 / 2}\right)$ and time to $50 \%$ loss in lysimeters (DT50) were calculated assuming that degradation follows first-order kinetics. The first-order constants were derived from the slopes of the linear regression of the logarithm of the concentration against time, assuming the linear relationship

$$
\ln \mathrm{C}=\ln \mathrm{C}_{0}-\mathrm{kt}
$$

where $\mathrm{C}_{0}$ is the initial concentration and $\mathrm{k}$ is the rate constant. Half-lives and $50 \%$ dissipation times were calculated from the relation $\ln 2 / \mathrm{k}$.

The effect of temperature on degradation was expressed using the Arrhenius equation:

$$
\log \left(\mathrm{H}_{\mathbf{l}} / \mathrm{H}_{2}\right)=(\mathrm{Ea} / 4.575)\left(1 / \mathrm{T}_{\mathbf{l}}-1 / \mathrm{T}_{2}\right)
$$

where Ea is the activation energy (cal mol-1), $\mathrm{H}_{1}$ and $\mathrm{H}_{2}$ are the half-lives (days) at temperatures $T_{1}$ and $T_{2}(K)$, and 4.575 is a constant equal to $R /\left(\log _{10} \mathrm{e}\right)$, where $\mathrm{R}$ is the universal gas constant (cal K-1 $\mathrm{mol}^{-1}$ ). 
The effect of temperature on degradation was also evaluated using a $Q_{10}$ factor calculated as the ratio between the $k$ rates at the two temperatures $T_{1}$ and $T_{2}$, which differed by $10^{\circ} \mathrm{C}$.

The effects of moisture were evaluated using an empirical equation developed by Walker (1978):

$$
\mathrm{H}=\mathrm{AM}^{-\mathrm{B}}
$$

where $\mathrm{H}$ is the half-life (d) at soil moisture $\mathrm{M}(\%, \mathrm{w} / \mathrm{w})$, $\mathrm{A}$ is the half-life (d) at zero moisture content and B represents the sensitivity of herbicide degradation to soil water content.

The adsorption parameters $\mathrm{k}_{\mathrm{f}}$ (Freundlich constant) and $1 / n$ (power coefficient) were derived using the Freundlich equation, that is

$$
\mathrm{x} / \mathrm{m}=\mathrm{k}_{\mathrm{f}} \mathrm{C}^{1 / n}
$$

(in logarithmic form: $\log x / m=\log k_{f}+1 / n \log C$ ), where $\mathrm{x} / \mathrm{m}$ is the ratio of pesticide to adsorbent mass and $\mathrm{C}$ is the equilibrium concentration of the adsorbate. When $1 / n$ is equal to unity, the Freundlich constant $k_{f}$ becomes independent of the equilibrium concentration of the adsorbate and is a $\mathrm{k}_{\mathrm{d}}$ (distribution coefficient), suitable to calculate $\mathrm{k}_{o c}$ (organic carbon partition coefficient), which is defined by

$$
\mathrm{k}_{\mathrm{oc}}=\left(\mathrm{k}_{\mathrm{d}} / \% \mathrm{oc}\right) 100
$$

where oc is the organic carbon content of soil.

\section{RESULTS AND DISCUSSION}

Figure 1 shows the degradation of metamitron in the laboratory at different temperatures and soil moisture contents. In all cases degradation follows first-order kinetics (r significant at $P \leq 0.001$ ). Half-life values were $18.8 \mathrm{~d}$ at $20{ }^{\circ} \mathrm{C}$ and $75 \% \mathrm{fc}$,
$25.8 \mathrm{~d}$ at $20{ }^{\circ} \mathrm{C}$ and $33 \% \mathrm{fc}$, and $56.3 \mathrm{~d}$ at $10{ }^{\circ} \mathrm{C}$ and $75 \%$ fc. The effect of temperature and soil moisture on degradation was evident. The effect of temperature was evaluated by $\mathrm{Q}_{10}$ and Ea values and that of moisture by $\mathrm{A}$ and $\mathrm{B}$ values (table III). The Ea value was similar to those found for metamitron by Walker (1978) and Capri et al (1995). While Walker et al (1996) suggested a mean $\mathrm{Q}_{10}$ value of 2.2 calculated for 140 pesticides, the value found in this experiment was slightly higher (2.99) thus confirming the strong influence of temperature on metamitron degradation.

The A and B values were 99.66 and 0.386 , respectively. In a previous paper Ferris and Haigh (1992) summarized A and B values for a range of herbicides as the mean of the A parameter $4,032 \mathrm{~d}$ and the standard deviation $18,580 \mathrm{~d}$, and the mean of B values 0.8 and standard deviation 0.53 . They found that the relationship between soil water content and herbicide degradation was significant, with herbicide half-life increasing by $80 \%$ for each $50 \%$ decrease in soil water content, but there was a poor correlation between A and B parameters. Therefore, these parameters are to be considered as site specific.

In the present experiment, the influence of soil moisture on degradation seemed very poor since the increase in half-life was $37 \%$ for a decrease in soil moisture of $50 \%$. The values found for $A$ and B parameters were lower than those found for metamitron by Walker (1978) and than the means found by Ferris and Haigh (1992).

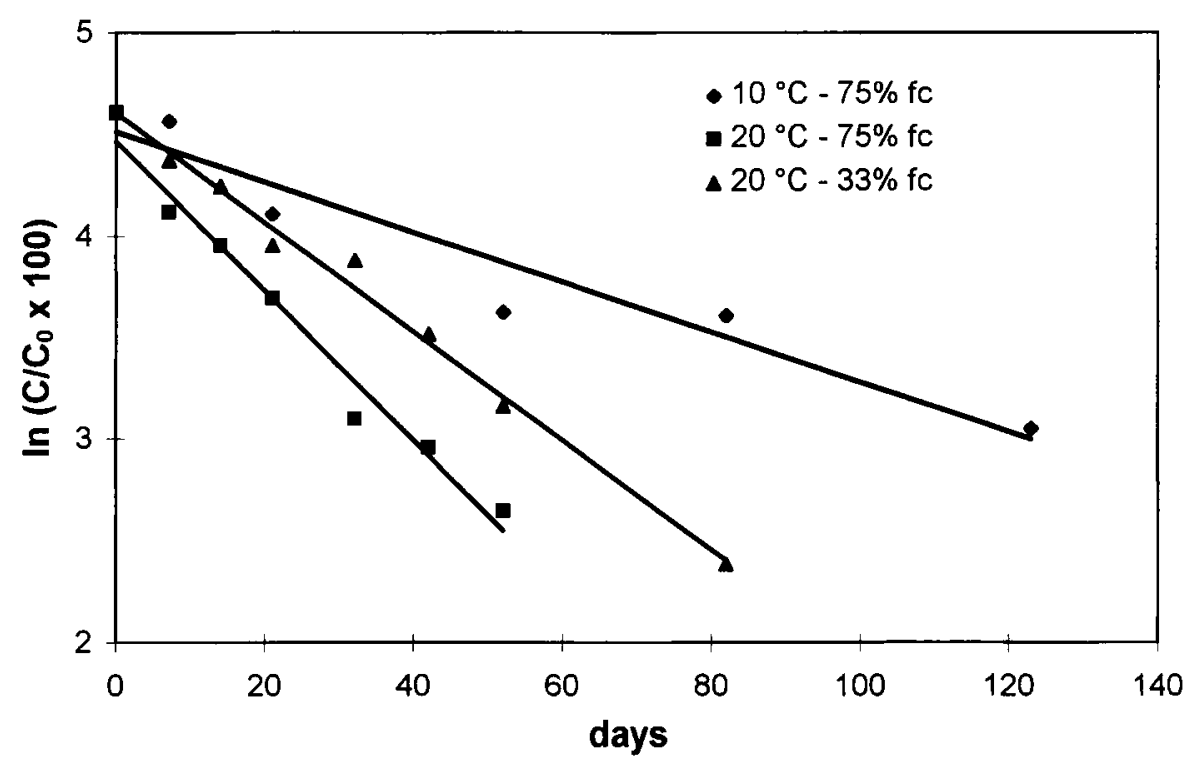

Fig 1. Degradation of metamitron in soil under different temperature and soil moisture conditions $(\mathrm{fc}=$ field capacity $)$. 
Table III. Degradation parameters for metamitron in laboratory and lysimeter studies.

a. Laboratory

\begin{tabular}{|c|c|c|c|c|c|c|}
\hline \multirow[b]{2}{*}{ Conditions } & \multirow[b]{2}{*}{$t_{1 / 2}$} & \multirow[b]{2}{*}{$R^{2}$} & \multicolumn{2}{|c|}{ Temperature effect } & \multicolumn{2}{|c|}{ Moisture effect } \\
\hline & & & $E a\left(\mathrm{cal} \mathrm{mol}^{-1}\right)$ & $Q_{10}$ & $A$ (days) & $B$ \\
\hline $20{ }^{\circ} \mathrm{C} 75 \% \mathrm{fc}$ & 18.83 & 0.975 & 18.149 & 2.99 & 99.66 & 0.384 \\
\hline $20{ }^{\circ} \mathrm{C} 33 \%$ fc & 25.86 & 0.991 & & & & \\
\hline $10^{\circ} \mathrm{C} 75 \%$ fc & 56.35 & 0.934 & & & & \\
\hline
\end{tabular}

b. Lysimeters

\begin{tabular}{lll}
\hline Lysimeters $n^{\circ}$ & DT50 & $R^{2}$ \\
\hline $1-2$ & 6.70 & 0.918 \\
$3-4$ & 8.05 & 0.932 \\
$5-6$ & 4.44 & 0.916 \\
\hline
\end{tabular}

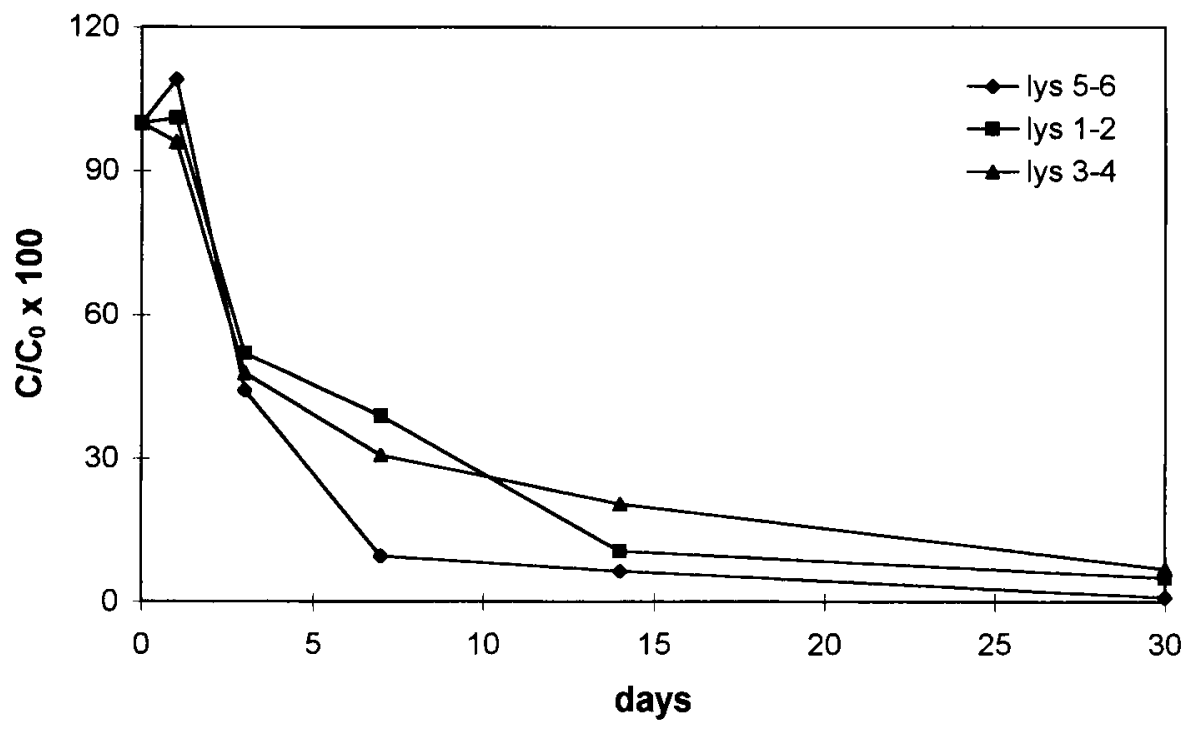

Fig 2. Dissipation of metamitron in lysimeters.

The dissipation studies (fig 2) showed that dissipation was faster in the more-leached lysimeters 5 and 6 than the other four lysimeters. However, DT50 values (table III), though different up to a two-fold increase (from 4.4 to 8.1 ), were similar from a practical point of view, indicating a fast dissipation in the conditions tested, independently of the different amounts of water used. This might be due to dissipation means other than leaching and enhanced by experimental factors, such as high temperatures and soil moistures and the relatively high soil content of organic matter $(2.8 \%)$.

Figure 3 shows the Freundlich isotherm for metamitron. The value of $\mathrm{k}_{\mathrm{f}}$ found in this experiment (1.71) was three times greater than that reported by Franco et al (1997), which was 0.61 in a sandy clay loam soil with 2.92 organic carbon and $\mathrm{pH}=6.1$, and the $1 / n$ value of 0.51 was not consistent with the findings in the above study (2.06) and indicated that sorption coefficients varied greatly according to the initial concentration of pesticide solution (L-type curve). In the light of this, $\mathrm{k}_{\mathrm{oc}}$ is an unreliable parameter to describe the sorption characteristics of metamitron in this study and the $\mathrm{k}_{\mathrm{f}}$ value coupled with $1 / n$ value should be used. Neverthless, the $K_{o c}$ value calculated was 128.2 , ranking metamitron among those pesticides intermediately risky for groundwater contamination.

Table IV shows the distribution of metamitron in soil for replicate lysimeters for each of the three irrigation treatments in table II. The water used in lysimeters 1 and 2 represents the effective need for sugar beet crops in the climatic conditions of 


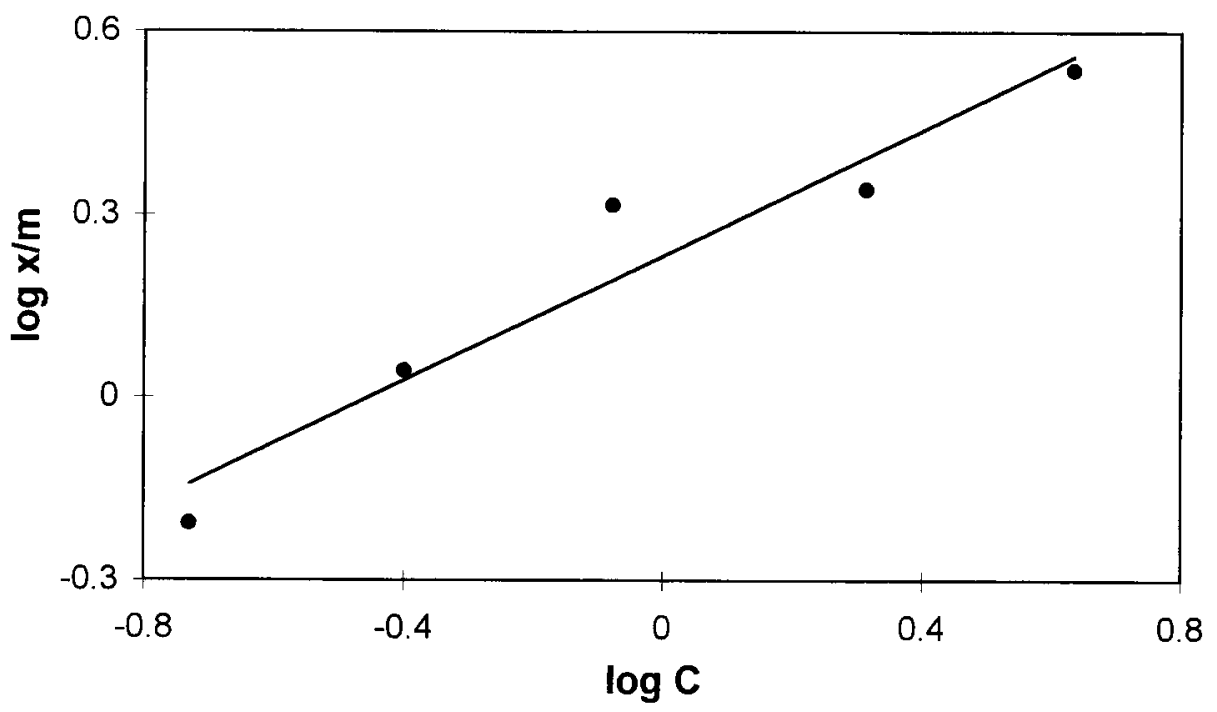

Fig 3. Adsorption isotherm for metamitron.

Table IV. Concentration of metamitron $\left(\mu \mathrm{g} \mathrm{kg}^{-1}\right)$ in the profile of the three lysimeter pairs (mean of four data \pm standard deviation).

\begin{tabular}{|c|c|c|c|c|c|c|c|}
\hline \multirow[t]{2}{*}{ Days } & \multirow[t]{2}{*}{ Lysimeter } & \multicolumn{6}{|c|}{ Depth $(\mathrm{cm})$} \\
\hline & & $0-10$ & $10-20$ & $20-30$ & $30-60$ & $60-90$ & $90-120$ \\
\hline 0 & $\begin{array}{l}5-6 \\
1-2 \\
3-4\end{array}$ & $\begin{array}{l}2938 \pm 531 \\
2501 \pm 689 \\
2761 \pm 698\end{array}$ & & & & & \\
\hline 1 & $\begin{array}{l}5-6 \\
1-2 \\
3-4\end{array}$ & $\begin{array}{l}2618 \pm 1193 \\
1600 \pm 370 \\
2053 \pm 557\end{array}$ & $\begin{array}{l}586 \pm 444 \\
928 \pm 249 \\
596 \pm 134\end{array}$ & & & & \\
\hline 3 & $\begin{array}{l}5-6 \\
1-2 \\
3-4\end{array}$ & $\begin{array}{l}392 \pm 333 \\
898 \pm 477 \\
796 \pm 234\end{array}$ & $\begin{array}{l}738 \pm 789 \\
333 \pm 198 \\
400 \pm 302\end{array}$ & $\begin{array}{l}82 \pm 55 \\
43 \pm 16 \\
58 \pm 17\end{array}$ & $\begin{array}{l}87 \pm 84 \\
25 \pm 15 \\
67 \pm 13\end{array}$ & & \\
\hline 7 & $\begin{array}{l}5-6 \\
1-2 \\
3-4\end{array}$ & $\begin{array}{l}172 \pm 66 \\
637 \pm 250 \\
561 \pm 171\end{array}$ & $\begin{array}{c}56 \pm 35 \\
60 \pm 47 \\
202 \pm 122\end{array}$ & $\begin{aligned} 36 & \pm 32 \\
238 & \pm 259 \\
56 & \pm 16\end{aligned}$ & $\begin{array}{l}11 \pm 13 \\
38 \pm 43 \\
25 \pm 10\end{array}$ & $6 \pm 8$ & \\
\hline 14 & $\begin{array}{l}5-6 \\
1-2 \\
3-4\end{array}$ & $\begin{array}{c}65 \pm 50 \\
114 \pm 65 \\
422 \pm 165\end{array}$ & $\begin{array}{l}56 \pm 36 \\
37 \pm 21 \\
82 \pm 33\end{array}$ & $\begin{array}{l}47 \pm 11 \\
17 \pm 8 \\
36 \pm 4\end{array}$ & $\begin{array}{l}17 \pm 12 \\
15 \pm 4 \\
24 \pm 6\end{array}$ & $\begin{array}{c}2 \pm 1 \\
46 \pm 49\end{array}$ & $35 \pm 42$ \\
\hline 30 & $\begin{array}{l}5-6 \\
1-2 \\
3-4\end{array}$ & $\begin{array}{c}4 \pm 3 \\
51 \pm 33 \\
104 \pm 66\end{array}$ & $\begin{array}{c}8 \pm 9 \\
33 \pm 37 \\
80 \pm 52\end{array}$ & $\begin{array}{c}7 \pm 9 \\
34 \pm 31 \\
6 \pm 7\end{array}$ & $\begin{array}{l}8 \pm 8 \\
7 \pm 7\end{array}$ & & \\
\hline
\end{tabular}

northern Italy and the movement of metamitron in these lysimeters supposedly represents a real situation. The pesticide reached $60 \mathrm{~cm}$ in depth at day 3 after treatment and $120 \mathrm{~cm}$ in depth at day 14. In lysimeters 3 and 4 sugar beet was cropped with small quantities of water in the first $21 \mathrm{~d}$, similar to those of lysimeters 1 and 2; during this period the movement of metamitron in the lysimeters was similar to lysimeters 1 and 2, with a sole difference at day 14 after treatment when metamitron remained in the first $60 \mathrm{~cm}$ of the soil profile. No water ever leached from the above four lysimeters throughout the entire experimental period but the depth reached by metamitron indicates a probable groundwater pollution risk. On the other hand, the fast dissipation observed (table III) by means other than leaching, reduced this risk to a certain extent. 
Two abundant leachings were performed in lysimeters 5 and 6 at days 4 and 56 after treatment. This was carried out to attain a worst case situation with a rapid passage of water through the lysimeters. At day 4 it resulted in drainages of $78 \mathrm{~mm}$ from lysimeter 5 and $127 \mathrm{~mm}$ from lysimeter 6 . The total amounts of metamitron found in these leachates were $28.82 \mathrm{mg}$ ( $3.9 \%$ of applied) and $101.5 \mathrm{mg}$ ( $15.7 \%$ of applied) for lysimeters 5 and 6 , respectively. The risk for groundwater pollution, which often occurs in northern Italy in spring, is evident in this situation. The leachates collected from the lysimeters 5 and 6 at day 56 presented no traces of pesticide, which presumably by this time was almost completely dissipated.

\section{CONCLUSIONS}

Metamitron degradation in soil followed firstorder kinetics and was affected by temperature and soil moisture content. Sorption in soil was well represented by an L-type curve with adsorption being relatively greater at low solution concentrations. $\mathrm{K}_{\mathrm{oc}}$ was not a reliable parameter to describe metamitron adsorption; however, its value $\left(128.5 \mathrm{~L} \mathrm{~kg}^{-1}\right)$ suggests a possibility of leaching to groundwater.

Metamitron movement through the lysimeter soil profile was affected by the different amounts of water applied. The marked movement of the pesticide in normal conditions means that the compound could be considered a potential pollutant in irrigated crops but, the rapid disappearence of the pesticide (DT50 4-8 days) by means other than leaching, reduced this risk somewhat.

\section{REFERENCES}

Allen R, Walker A (1978) The influence of soil properties on the rates of degradation of metamitron, metazachlor and metribuzin. Pestic Sci 18,95-111
Capri E, Ghebbioni C, Trevisan M (1995) Metamitron and chloridazon dissipation in a silty clay loam soil. $J$ Agric Food Chem 43, 247-253

Ferris IG, Haigh BM (1992) Prediction of herbicide persistence and phytotoxicity of residues. In: Proceedings of the First International Weed Control Congress, Monash University, Melbourne, Australia, vol I, 193-207

Franco I, Vischetti C, Baca MT, De Nobili M, Mondini C, Leita L (1997) Sorption of linuron and metamitron on soil and peats at two different decomposition stages. J Soil Contamination 6 (3), 307-315

Ghebbioni C, Trevisan M (1992) Determination of sugarbeet herbicides in soil samples by HPLC. Pestic Sci 34, 105-107

Klute A (1986) Methods of Soil Analysis Part I, 2nd ed. American Society of Agronomy Inc, Soil Science Society of America, Madison, WI, USA

Page AL (1982) Methods of Soil Analysis Part 2, 2nd ed. American Society of Agronomy Inc, Soil Science Society of America, Madison, WI, USA

Trevisan M, Capri E, Del Re AAM, Vischetti C, Marini M, Businelli M, Donnarumma L, Conte E, Imbroglini G (1995) Evaluation of pesticide leaching models using three italian data-sets. In: $B C P C$ Monograph $n^{\circ}$ 62: Pesticide movement to water (Walker A, Allen R, Bailey SW, Blair AM, Brown CD, Gunther P, Leake CR, Nicholls PH, eds), British Crop Protection Council, Farnham, Surrey, UK, 269-274

Vischetti C, Marini M, Businelli M, Onofri A (1996) The effect of temperature and coapplied herbicides on the degradation rate of phenmedipham, chloridazon and metamitron in a clay loam soil in the laboratory. In: The Environmental Fate of Xenobiotics (Del Re AAM, Capri E, Evans SP, Trevisan M, eds), La Goliardica Pavese, Pavia, Italy, 287-294

Walker A (1978) Simulation of the persistence of eight soil-applied herbicides. Weed Res 18, 305-313

Walker A, Helweg A, Jacobsen OS (1996) Temperature and pesticide degradation. In: Soil Persistence and EU Registration. The final report of the work of the Soil Modelling Work Group of FOCUS, 9-20 